\title{
The concept family in the Russian and Ukrainian language culture (based on proverbs and sayings)
}

\author{
Tatyana Romanova ${ }^{1}$, Olga Evdokimova $^{1}$, Anna Zaharova ${ }^{1, *}$, Alena Ivanova ${ }^{1}$, Nadezhda Fedorova $^{1}$ \\ ${ }^{1}$ Chuvash State University named after Ulyanov I.N, 428017, Cheboksary, Russia
}

\begin{abstract}
The article studies features of verbalization of the concept family. Based on the extensive proverbial material, the system of value attitudes and stereotypical representations of family as a traditional social institution in the understanding of Russian and Ukrainian peoples is analyzed: the role of family and marriage in the culture of Russians and Ukrainians, stages of family formation including selection of a bride or a groom, distribution of family duties, and the role of parents, attitude towards step-children. As a result of the comparative analysis of Russian and Ukrainian paremias in which family relations are reflected, general and national-specific features related to mentality, value preferences, customs and traditions of close Slavic ethnic groups are revealed. It was concluded that despite the specific features of the material and spiritual culture of Russian and Ukrainian peoples, the understanding of family and its role in human life is similar. This coincidence proves that the main functions of family as a small social group based on marriage and consanguinity are education of children and preservation of national and universal values.
\end{abstract}

\section{Introduction}

Currently, when the world can no longer live in isolation, one of the most relevant areas of anthropocentric linguistic research is historical, cultural and linguistic traditions. Language as a means of transmitting cultural information reflects culture of people, their worldview, features of material and spiritual life which allows us to view linguistics as a compulsory part of humanitarian knowledge forming personality [1].

Values and stereotypes are verbalized in proverbs and sayings, representing "commandments of truth that have turned into worldly wisdom." [2] Proverbs and sayings have been recorded for a long time being reflected in figurative statements that regulate economic and social activities. The concept "family" is presented in paremias which are a means of representing various linguistic and cultural realities [3].

In modern society, family is an important component of universal human culture which keeps traditional national values. In the context of the ongoing social changes - the growth of national identity, returning to the roots, and breaking stereotypes, changing attitudes towards family values, it is very important to maintain an understanding of family as a traditional social institution - a community of people connected by blood relationship and common life and mutual responsibility. In this regard, the study of paremias which reflects universal and national family values is relevant.

The study of the concept in general and the concept "family" in particular was carried out on the basis of various languages [4-6], including in terms of their comparison [7-10]. Particular attention is given to equivalent concepts which allows us to identify features of national mentality and identify similarities and differences in the linguistic cultures of different peoples [11].

The purpose is to show how the concept "family" is reflected in the proverbs and sayings of two Slavic peoples - Russian and Ukrainian ones, to describe the system of stereotypical representations of the family, to identify general and specific features of mentality, moral values, customs and traditions of different ethnic groups.

\section{Materials and methods}

A theoretical analysis of national and foreign scientific literature allowed us to determine methodological foundations and conceptual ideas of the study. The analogy method and systematic approach were used in studying the language material [2]. Due to the systematic approach, the most common linguistic and cultural patterns of an understanding of family relations in the Russian and Ukrainian languages were identified. The synergetic approach, according to which complex open systems are considered as self-organizing, is used to study the evolution of historical and cultural traditions that have developed in two related languages. Using the empirical methods, in particular observation, the results can be used when teaching "Actual problems of modern linguistics", general and comparative linguistics, writing diploma theses, etc.

The material and research methods are determined by the aim to show national features of two Slavic languages that have common roots and history.

* Corresponding author: zaharova_an@mail.ru 


\section{Discussion and conclusion}

Traditionally, family was understood as "a group of relatives living together; parents with children; a married son or a married daughter living separately from another family" [16]. Accordingly, it is necessary to distinguish between a large family with an expanded composition and including several generations of relatives living together, and a small family consisting of a married couple and excluding married children. This article is based on the understanding of family as a small social group based on marriage and blood relationship.

Our analysis of proverbs and sayings of Russian and Ukrainian peoples revealed productivity of paremias characterizing family relationships. This is not accidental: family in Slavic culture has always been an integral part of life. Happiness has been associated with the well-being of family: Rus. Семья - опора счастья; Ukr. Без сім' $і$ немає щастя на землі. In accordance with the popular ideas, a man should not live alone, family is a reliable stronghold and protection, it gives rise to a new life; therefore, family is a vital need for both man and woman: Rus. И в раю жить тошно одному; Не женат - не человек; Семья воюет, а одинокий горюет; Ukr. Де одинець - хазяйству кінецьь, де сім - щзастя всім.

Researchers say that the Russians considered it suspicious if a person in adulthood remained a bachelor [17]; according to popular beliefs, Ukrainians could not appear without a wife even in the next world [18]. Men and women who did not create families were disapproved. It is reflected in both Russian and Ukrainian paremias: Rus. Много невест разбирать - век женатому не бывать; Старое мясо не уваришь, старого жениха не оженишь; Ukr. Перестояна трава - ні сіно, ні солома, а стара дівка - ні жінка, ні вдова; Старого парубка женити як старее м'ясо варити.

Despite the fact that marriage was originally based on economic interests and pragmatic goals, an analysis showed that love was considered an important condition for marriage (Rus. Где любовь, там свет; Человек по сердиу - половина вениа; Ukr. Коли люб, гарний шлюб. The family based on love and harmony was able to perform economic, reproductive, educational, social and other functions: Rus. В семье любовь да совет, так и нужды нет; Ukr. Не потрібен і клад, коли у чоловіка з жінкою лад.

It is noteworthy that folk wisdom reflected in proverbs and sayings represents all the stages of family formation starting with the choice of a bride or groom (Жениться легко ошибиться; Жениться - не лапоть надеть; Замуж выходи - в оба гляди). Marriage is the most important step in life, which changes the social status of a person and imposes new responsibilities on both a man and a woman. In this regard, the choice of a wife or a husband became sacred; therefore, one of the crucial conditions was caution, prudence (Rus. Выбирай жену не в хороводе, а в огороде; Глядя на мать, бери дочь; Ukr. Перш ніж одружитись, треба роздивитись; Траву дивись у день, як обсохне роса, а дівку у будень, як невбрана та боса.

It is noteworthy that when choosing, the bride should have had housekeeping abilities, to be a good wife and mother; the bride's main virtues were health, industriousness and chastity: Rus. Жену выбирай не глазами, а по доброй славе; Не бери богатую, бери непочатую; Не богатство, а честь невесту красит; Ukr. Честь дівоче щастя береже. When choosing a bride, it was necessary to take into account her origin; preference was given to economically and socially equal marriages: Rus. Равные обычаи - крепкая любовь; Ukr. Ворона до ворони сідає, кожний рівного собі шукає.

Observations show that proverbs reflected negative ideas about marriage as well, which speaks for moral preferences of the ancient Slavs, revealing the depth of their understanding of marriage, its paramount importance in human life. The proverbs contain a warning against rash decisions, which include:

- hasty marriage (Rus. Не заламывай рябину не вызревши, не бери девку не вызнавши; Женился скоро, да на долгое горе; Женишься раз, а плачешься век; Свадьба скорая что вода полая; Ukr. Оженився на скору руку та на довгу муку;

- inability to maintain family (Rus. Тогда женись, когда деньги завелись; Ukr. Сорочки немає, а женитися гадає;

- marriage of convenience (Rus. Лучше на убогой жениться, чем с богатой браниться; Не жить с приданым, а жить с богоданным; Ukr. Краще в ставку потопати, як з нелюбим шлюбузяти (букв. Лучше в пруду утонуть, чем выйти замуж на нелюбимого; Не з багатством жити, а з людиною; Як люба дружина, то люба й в ряднині;

- unequal marriage (Rus. По себе дерево руби, по себе жену бери; Ukr. Не спаруєш голубки до півня, бо голубка півневі не рівня), especially with an older person (Rus. За старым жить - только век должить; Ukr. Де чоловік старий, ажінка молода, там вогонь $і$ вода, or representatives of other nationalities).

Family is a single organism whose coordinated work is a source of moral values, material well-being and social status; "husband and wife reflect the very essence of the concept "family", being its progenitors» [19]: Rus. Между мужем женой нитки не протащишь; Муж и жена - из одного кремня искры; Муж да жена - одна сатана; Муж да жена - душа одна; Ukr. Чоловік та жінка - одне болото. In the Patriarchal family, there was a clear distribution of responsibilities: the husband worked in the yard and in the field - where physical strength was required, and the wife was mainly engaged in housekeeping and upbringing of children: Rus. Муж вези гуж, а жена шей рубашки; Ukr. Без хазяїна двір, без хазяйки хата плаче; Од господаря повинно пахнути вітром, а од господині - димом.

The dominant position in family was assigned to a husband (Rus. Худо тому, у кого жена хозяйкой в дому; Ukr. Чоловік жоні закон; Чоловік - усьому голова) who he took care of the material well-being of family, monitored the observance of customs that ensure a reliable reputation of family, distributed the inheritance, gave permission for marriage of children, and punished his wife for any fault (Rus. Жене спускать - добра не видать; Ukr. Люби жінку, як душу, а тряси, як грушу; Хто жіниі волю дає, той сам себе б'є.

Despite the dependent position, the wife was protected and even happy with her husband, especially if he was a good man and a zealous host (Rus. За мужа завалюсь - 
ничего не боюсь; За хорошим мужем и жена хороша; Ukr. Нашуо й гроші, коли чоловік хороший. Without a husband, she experienced material difficulties and mental suffering. This side of family life is also reflected in proverbs (Rus. Жена без мужа - вдовы хуже; Жена без мужа - конь без узды; Какой бы муж ни ворона, но жене оборона; Ukr. Краще сім раз горіти, аніж один раз овдовіти.

The wife played an important role in preserving family. She must be a good housewife, help her husband, do household work and raise children: Rus. Как хорошая жена да жирные щи, так другого добра не ищи; Хозяйка в дому - что оладьи в меду; Ukr. Нема кращчого друга, як вірна супруга. Despite the presence of proverbs and sayings indicating female disempowerment, subordination and violence, there are numerous evidences that the wife also had authority and, after the death of her husband, she became the family head representing family interests at general meetings [17].

Much attention is paid to the image of a negative attitude to vices that destroy family:

- laziness, mismanagement Rus. В прилежном доме густо, а в ленивом доме пусто; Возьмешь дурунеряху, не сошьет мужу рубаху; Лучше черта любить, чем с ленивой жить; Ukr. За ледачим чоловіком жінка марніє, за хорошим -молодіє;

- grumpiness, bad temper (Rus. Лучше жить со змеею, чем со злою женою; Сварливая жена - в доме пожар; Когда муж с женой бранится, тогда и гориок не варится; Ukr. Лучче їсти хліб з водою, чим жити з жінкою лихою;

- drunkenness (Rus. Пьянство - души потопление, семьи разорение; Ukr. Коли чоловік в шинку скаче, то жінка дома плаче;

- jealousy (Rus. Супружеская ревность - отрава жизни; Ревнивый муж шипит как уж; Ukr. Не дай Бог коня лінивого, а чоловіка ревнивого;

- cheating (Rus. В чужую жену черт мед кладет, 6 свою уксусу подливает; Чужая жена - лебедушка, а своя - полынь горькая; Ukr. На чужих жінок не задивляйся, а за своєю подивись; Чужого чоловіка полюбити - себе погубити; Драний кожух не одежа, чужий чоловік не надежа.

Despite the fact that the law allowed for divorces in case of impossible cohabitation, society was against them. A characteristic feature of Slavic mentality is as follows: unwritten laws which became proverbs turned out to more effective than written laws: Rus. Дай бог раз жениться, раз креститься и раз умирать; Женитьба есть разженитьбы нет; Поп свяжет - никто не развяжет; Смерть да жена Богом суждены; Умные сходятся, а дураки разводятся; Ukr. Все тільки до часу, а жінка до смерті; 3 ким вінчатися, з тимі кінчатися; Не дай, боже, два рази женитися та три раза свататися. In a difficult situation, the husband as a head of the family must be aware of his responsibility towards his wife: Rus. Знаться с кумою - расстаться с женою; Чужую жену полюбить - свою погубить; Ukr. I в лиху годину не кидай дружину; Не заглядайся на чужих жінок, бо свою згубиш.

Family cannot exist without children who were blood relatives of parents and for each other. They created a force of the family axis" [20]. Children are a core of family life in many proverbs and sayings: Rus. Дети благодать божья; Дети не в тягость, а в радость; Дом с детьми - базар, без детей - могила; Супругам без ребятишек - что зимой без дровишек; У кого детей нет - во грехе живет; укр. Без гілок не дерево, без дітей-не сім'я. In addition, the proverbs emphasize the role of parents in raising children hardworking, obedient, respectful (Rus. Верная указка - не кулак, а ласка; Дитятко, что тесто: как замесил, так и выросло; Ukr. Годуй діда на печі, бо й сам будеш там; Не вчи дитину штурханцями, а хорошими слівцями; Яке дерево, такі його квіти; які батьки, такі й діти.

Patriarchal families were large. The gender of a newborn was also important, since the allotment of arable land was allocated only to a male child which means that the well-being of family depended on the number of men; daughters caused only expenses on weddings and dowry [17; 18]: Rus. Растить дочку, что лить в дырявую бочку; С сыном дом наживёшь, а с дочкой остаток проживёшь; Сын хлебом кормит, а дочь последний кусок унесёт; Ukr. Годуй сина для себе, а дочку - для людей; Дочку годувати - у вікно кидати; Сини принесуть, а дочки і вугли рознесуть.

Family legal relations could be based not only on consanguinity. In this regard, adoption is of great interest. It is the oldest Slavic custom according to which orphans were adopted and raised to their adulthood. One of the forms of adoption was adoption of orphans by childless families; adoption of children from poor large families or families of relatives; illegitimate children (with the consent of their mothers); boys, if family had only daughters. Children lived with foster parents until they have created their own families. Adopted children had the same rights as own children. All these features of family relations are reflected in Russian and Ukrainian proverbs which emphasize a high degree of spiritual kinship between two peoples: Rus. Не ma мать, которая родила, а та, которая вспоила-вскормила; Не тот батюшка, кто родит, а тот, кто уму-разуму научит; Не тот отеи, кто родил, а тот, кто вспоил, вскормил, да добру научил; Ukr. Не та мати, щзо народила, а та, яка виховала й вигодувала; Не той батько, щчо зродив, а той, щчо до ума довів.

\section{Discussion and conclusion}

In the Russian and Ukrainian proverbs and sayings, life of a small family, its responsibilities and traditions are represented; legal norms regulating personal non-property relations of husbands and wives and other family members are reflected; recommendations how to behave in different situations, household disputes are provided.

An analysis of paremias reflecting family legal relations showed that, despite specific features of material and spiritual culture of two peoples, an understanding of family is similar. An analysis of proverbs and sayings of another thematic group revealed less similarities due to the specifics of the worldview of these peoples [21, p. 48]. This is due to the fact that family is a social institution whose main functions are upbringing of the younger generation and preservation of national and universal values. 


\section{References}

1. O.K. Evdokimova, V.I. Gorbunov, V.V. Andreev, A.M. Ivanova, A.N. Zaharova. Methodology and Practice of Teaching of Philological Cycle Subjects at the Technical Faculties of Russian Universities. International Conference "Topical Problems of Philology and Didactics: Interdisciplinary Approach in Humanities and Social Sciences" (TPHD 2018). Advances in Social Science, Education and Humanities Research (ASSEHR), 312. 464-469. (2019).

2. I.M. Snegirev. Russians in their proverbs: reasoning and research on domestic proverbs and sayings. 184 (2012).

3. T.V. Babiyan. Proverbs and sayings as a means of representing linguistic and cultural realities. Philological sciences. Questions of theory and practice. Tambov: Gramota. 10 (76): in 3 parts. Part 2. 48-50. (2017).

4. E.A. Glotova. Family in Russian national consciousness. Humanitarian research. 3 (4). 47-50. (2014).

5. M.B. Ketenchiev, A.T. Dodueva, A.A. Deveeva. Family Verbalization in Karachay-Balkarian folklore. Baltic Humanitarian Journal. 7. 1 (22). 81-84. (2018).

6. M. Kitanova. Bulgarian proverbs about the family (features of the national mentality). The Slavic world in the third millennium: man, society, people in history, language and culture. Moscow: ISL RAS. 285-294. (2014).

7. E.I. Kolosova. Family Institute in the Conceptosphere of Russian and Polish. Scientific notes of Kazan University. Series Humanities.156. 5. 114-119. (2014).

8. I.A. Selezneva, L.V. Babin. Objectification of ideas about the family in Russian, English and Chinese. Philological sciences. Questions of theory and practice. Tambov: Gramota.. 12. 2. 139-144. (2019).

9. E.S. Tarasova. Images of husband and wife in English and Russian paremiology: linguistic and cultural aspect. Philological sciences. Questions of theory and practice. Tambov: Gramota. 12 (5). 363-367. (2019)
10. A.O. Ryzhkina. Conceptual analysis of representation of the concept family in Chinese, English and Ukrainian. Bulletin of Dnepropetrovsk University. 22 (20-2). 148-152. (2014).

11. M.V. Pimenova. Conceptual research and national mentality. Humanitarian vector. 4 (28). 126-132. (2011).

12. V.I. Dahl. Proverbs and sayings of the Russian people. 640 (2007).

13. V.I. Zimin, A.S. Spirin. Proverbs and sayings of the Russian people: a large explanatory dictionary. Ed. $3 r d$, stereotypical. Rostov-on-Don: PHOENIX, Moscow: CITADEL-TRADE. 544 (2006).

14. A.V. Markovich et al. Ukrainian sayings, proverbs and so on (Libid, Kiev, 1993).

15.S. Mishanich and M. Pazyak, comp. Ukrainian sayings and proverbs. (Dnipro, Kiev, 1983)

16. V.I. Dahl. Explanatory Dictionary of the Living Great Russian Language: in 4 vols. 4. Moscow: Rus. lang 684 (1991).

17. Yu.S. Ryabtsev. History of Russian culture: artistic life and life of the XI-XVII centuries. Moscow.: Humanity. ed. Center VLADOS. 336(1997).

18. A.P. Ponomaryov, L.F. Artukh, T.V. Kosminatain. K.: Lebed. Eds Ukranian illustrated ethnographic dictionary 256 (1994).

19. L.R. Shamsutdinova, F.G. Fatkullina. Structural and grammatical characteristic of phraseological units and paremias characterizing family relationships. Philological sciences. Questions of theory and practice. Tambov: Gramota. 11 (89). Part 2. 404-408. (2018).

20. A.B. Belyaev. Traditional family values. Bulletin of the Tambov University. 11 (67). Series: Humanities. 170-175. (2008).

21. T.N. Romanova. Linguoculturological aspect of Russian and Ukrainian paremias with xenoethnonymic components. Ashmarin readings: a collection of materials of the XI International scientific-practical conference. Cheboksary: Publishing house of the Chuvash University. 46-48. (2019). 